\title{
Діагностична та прогностична значущість активності фосфоліпази А2, амілази, рівнів гістаміну та ендотеліально- моноцитарного активуючого пептиду II в сироватці крові при різних формах гострого панкреатиту
}

\author{
В. В. Міщук, Н. Я. Іваночко \\ Івано-Франківський національний медичний університет
}

\section{Diagnosis and prognostic significance of activity of phospholipase A2, amylase, levels of histamine and endothelial-monocytic activating peptide II in the blood serum in various forms of an acute pancreatitis}

\author{
V. V. Mishchuk, N. Ya. Ivanochko \\ Ivano-Frankivsk National Medical University
}

\section{Реферат}

Мета. Вивчити інформативну значущість різного ступеня підвищення активності фосфоліпази А2, амілази, рівнів гістаміну, ендотеліально-моноцитарного активуючого поліпептиду II (ЕМАП-II) як маркерів глибини ураження підшлункової залози (ПЗ) при гострому панкреатиті (ГП).

Матеріали і методи. У 45 хворих, прооперованих з приводу тяжкої форми ГП, яким після лапароскопічного дослідження і виявлення розлитого ферментативного перитоніту дренували сальниковий отвір, розкривали і дренували зону некрозу, та у 28 хворих із ГП середнього ступеня тяжкості, яким проводили консервативну терапію, під час госпіталізації визначали активність фосфоліпази А2, рівні гістаміну, ЕМАП-ІІ імуноферментними методами та активність амілази кінетичним методом.

Результати. При ГП середнього ступеня тяжкості активність амілази до початку терапії підвищувалась до $(249,5 \pm 16,2)$ од/л у 71,43\% хворих, при тяжкому (деструктивному) - до $(329,77 \pm 24,2)$ од/л у 53,3\% хворих (р < 0,05). Активність фосфоліпази А2 підвищувалась до $(698,18 \pm 9,70)$ нг/мл у всіх обстежених хворих із деструктивним панкреатитом та до $(392,77 \pm 15,59)$ нг $/$ мл при ГП середнього ступеня тяжкості $(\mathrm{p}<0,05)$. Рівень гістаміну у хворих із ГП середнього ступеня тяжкості становив $(2,28 \pm 0,12)$ нг/мл, у разі деструкції ПЗ - $(5,10 \pm 0,34)$ нг/мл (у здорових осіб - $(0,70 \pm 0,11)$ нг/мл). Розвиток таких ускладнень, як панкреатогенний перитоніт, має велику вірогідність (відношення шансів, odds ratio-OR становить 103,14) ( $<$ 0,0001) у разі підвищення активності фосфоліпази А2 понад 392,77 нг/мл.

Висновки. Висока активність фосфоліпази А2 і підвищений рівень гістаміну в сироватці крові у хворих із ГП на початковій стадії є більш прогностично вірогідними маркерами тяжкого його перебігу та розвитку ускладнень.

Ключові слова: гострий панкреатит; фосфоліпаза А2; гістамін; амілаза.

Abstract

Objective. To study the informative significance of various degree of the activity rising for phospholipase A2, amylase, levels of histamine and endothelial-monocytic activating polypeptide II (EMAP-II) as markers of depth of pancreatic affection in an acute pancreatitis (AP).

Materials and methods. Activity of phospholipase A2 (while applying kinetic method), amylase, levels of histamine and (EMAPII) were determined (using immunoassay methods) during a stationary stay in 45 patients, who were operated for severe form of an AP, using laparoscopic investigation and revealing of diffuse enzymatic peritonitis with the necrotic zone drainage, and in 28 patients, suffering a middle severity AP, to whom conservative therapy was conducted.

Results. In an AP of a middle severity the amylase activity before therapy have raised up to (249.5 \pm 16.2$) \mathrm{U} / 1$ in $71.43 \%$ patients, and in a severe (destructive) one - up to $(329.77 \pm 24.2) \mathrm{U} / \mathrm{L}$ in $53.3 \%$ patients $(\mathrm{p}<0.05)$. Activity of phospholipase A2 have raised up to $(698,18 \pm 9.70) \mathrm{ng} / \mathrm{ml}$ in all the examined patients, suffering destructive pancreatitis and up to (392.77 \pm 15.59$)$ $\mathrm{ng} / \mathrm{ml}$ - in an AP of a middle severity $(\mathrm{p}<0,05)$. Level of histamine in patients, suffering a middle severity AP have constituted $(2,28 \pm 0,12) \mathrm{ng} / \mathrm{ml}$, and in pancreatic destruction $-(5.10 \pm 0.34) \mathrm{ng} / \mathrm{ml}$ (in healthy persons $-(0.70 \pm 0.11) \mathrm{ng} / \mathrm{ml})$. Development of such complications, as pancreatogenic peritonitis, owes big possibility (OR constitutes 103.14) $(\mathrm{p}<0.0001)$ if activity of the phospholipase A2 activity would be over $392.77 \mathrm{ng} / \mathrm{ml}$.

Conclusion. High activity of phospholypase A2 and enhanced level of histamine in the blood serum in patients, suffering early stage of an AP, constitutes more prognostically probable markers for its course severity and the complications development. Keywords: acute pancreatitis; phospholipase A2; histamin; amylase.

Гострий панкреатит (ГП) - асептичне запалення ПЗ, при якому можливе ураження навколишніх тканин, віддалених органів та систем, зумовлене активацією фермен- тів у тканині самої залози [1]. В Україні захворюваність на ГП становить 102 спостереження на 100000 населення, а загальна летальність коливається від 4 до 15\% та зростає 
при некротичній формі до 24 - 60\% [2]. В окремих європейських країнах цей показник дещо нижчий - 72 спостереження на 100000 населення, хоча він теж має тенденцію до зростання [3]. Зменшенню смертності від ГП сприяє рання оцінка його тяжкості та своєчасне і в повному обсязі лікування [4]. ГП займає третє місце після гострого холециститу та апендициту в структурі невідкладних хірургічних захворювань [5]. Найчастіше зростання кількості хворих із ГП та частоти розвитку його ускладнень спричиняє зловживання алкоголем [6]. У країнах, де алкоголізм менш поширений, найбільш частою причиною ГП є жовчнокам'яна хвороба, що призводить до смерті 8\% хворих, у яких стався перший напад.

Ключовим патогенетичним механізмом ГП на початковій стадії є гіперферментемія, зокрема, надмірне виділення еластази, ліпази, фосфоліпази А2, лецитинази, трипсину, лізосомальних ферментів, які викликають некроз паренхіми, окислювальний стрес, ліпідний дистрес-синдром, тромбоз капілярів, гіпоксію, пошкодження мембран ацинарних клітин і ендотелію [7]. Аутоагресія з подальшим некрозом і дегенерацією тканини П3, заочеревинної клітковини та ураження органів - мішеней також супроводжуються приєднанням вторинної інфекції. Ферменти ПЗ активують калікреїн-кінінову систему 3 утворенням біологічно активних речовин, таких як брадикінін, гістамін, серотонін, що призводять до збільшення судинної проникності, порушення мікроциркуляції, підвищеної ексудації, мікротромбозу і ацидозу тканини Пз. Метаболіти різної природи, цитокіни, що утворюються в тканині ПЗ, жировій клітковині, стінках тонкої кишки, збільшують проникність останньої, транслокацію кишкової мікрофлори, надходження токсинів у портальний і системний кровоплин, лімфатичне русло з ураженням органів-мішеней. У залежності від ступеня тяжкості патогенетичних змін при ГП його перебіг може мати легку (mild acute pancreatitis), середньої тяжкості та тяжку форми. Останню в Україні діагностують у 15 - 25\% хворих, 15 - 20\% яких помирають [2].

Незважаючи на те що основою для встановлення діагнозу ГП після виключення іншої хірургічної патології $€$ інтенсивний, що майже не зменшується після прийому спазмолітиків біль у надпупковій зоні, який супроводжується неухильним блюванням і здуттям живота, збільшення розмірів ПЗ, зниження ехогенності, нечіткість ії контурів, наявність вільної рідини в черевній порожнині за результатами сонографії живота, діагностика ГП на початковій стадії має значні труднощі. Визначення активності сироваткової амілази та ліпази, яка перевищує норму в 3 і більше разів, не завжди відповідає тяжкості ГП, а нормальна їх активність в крові та сечі не дає підстав для виключення діагнозу ГП. Тому визначення активності даних маркерів, хоча іє важливим, не завжди може бути використано для уточнення тяжкості захворювання і підтвердження чи спростування такого діагнозу. У зв'язку з цим постійно ведеться пошук нових інформативних маркерів оцінки глибини пошкодження паренхіми ПЗ при ГП. Так, Б. М. Годлевський і співавтори [8] рекомендують 3 метою підтвердження ГП визначати в сечі рівень трипсиногену-2 як нетривалого та неінвазивного маркера глибо- кого пошкодження паренхіми П3. Інші автори для оцінки тяжкості ГП і прогнозування розвитку ускладнень пропонують досліджувати концентрацію Д-димеру та C-peактивного протеїну, хоча значення останнього як маркера гострої фази обмежене раннім періодом захворювання і лише його рівень вище 150 мг/л через 48 год після появи симптомів може вказувати на тяжкий панкреатит [9]. Також з метою оцінки тяжкості та диференціації форм ГП використовують визначення рівнів прозапальних цитокінів [10]. Ще одним ферментом, активність якого закономірно підвищується при ГП, є фосфоліпаза А2, а їі визначення дедалі частіше застосовують в діагностиці різних його форм [11]. Активність фосфоліпази А2 в крові відображає тяжкість панкреатиту, а гальмування іiі активності на експериментальних моделях in vitro та in vivo зменшувало глибину гострого ураження ПЗ. В поодиноких експериментальних дослідженнях встановлено, що активація ліполітичних ферментів, зокрема фосфоліпази А2, відіграє провідну роль у патогенезі ГП та корелює з тяжкістю захворювання. Фосфоліпаза А2 має тропність до ліпідів клітинних мембран, викликаючи їх пошкодження. Після гідролізу і відщеплення від фосфоліпідів вільних жирних кислот утворюються медіатори широкого спектру клітинних процесів прозапального характеру, що сприяють тканинному запаленню та порушенню гемостазу. Відщеплюючи жирну кислоту від лецитину, фосфоліпаза А2 сприяє утворенню лізолецитину, який, потрапляючи в головну протоку ПЗ, викликає спочатку набряк ії слизової оболонки, а через декілька хвилин - некроз паренхіми ПЗ. Активність фосфоліпази А2 в крові підвищується раніше та утримується на такому рівні триваліше, ніж активність амілази, ізоамілази, трипсину. Протеоліз також супроводжується накопиченням у тканині ПЗ гістидіну і перетворенням його в гістамін, який поглиблює порушення кровообігу в ній, викликаючи параліч капілярів. Вивільнений з тканини ПЗ калікреїн разом з трипсином розщеплює білки крові з утворенням брадикініну. Гістамін, калікреїн, брадикінін є агентами, під впливом яких настають зміни як внутрішньоорганної, так і периферичної та центральної гемодинаміки і розвиток системних уражень при некрозі П3 [12]. Значний інтерес викликає роль окремих цитокінів у патогенезі різних форм ГП, одним із них є ЕМАП-II, який бере активну участь в ангіогенезі, індукуючи апоптоз злущених клітин ендотелію та пошкоджених мікроорганізмами клітин ПЗ. Як видно з наведених даних, пошук найбільш інформативних маркерів глибини пошкодження ПЗ та диференціація різних клінічних форм ГП залишаються актуальними та до кінця не завершеними.

Мета дослідження: вивчити інформаційну значущість різних ступенів підвищення активності фосфоліпази А2, амілази, рівнів гістаміну, ЕМАП-II як маркерів глибини ураження ПЗ при ГП.

\section{Матеріали і методи дослідження}

У 45 прооперованих хворих із тяжкою формою ГП (severe acute pancreatitis), яким після лапароскопічної діагностики і виявлення розлитого ферментативного перитоніту виконували дренування сальникового отвору, роз- 
кривали і дренували зону некрозу, та у 28 пацієнтів з ГП середнього ступеня тяжкості, яких лікували консервативно, під час госпіталізації визначали активність фосфоліпази А2, амілази, рівні гістаміну та ЕМАП-ІІ в сироватці крові. Активність фосфоліпази А2 визначали імуноферментним методом із використанням набору Cauman Chemical Spla2 (human Type IIA) EIA (USA); рівень гістаміну - тим же методом із використанням наборів реагентів Histamine ELISA KIT (Німеччина); рівень ЕМАП-II - за допомогою твердофазного імуноферментного методу з використанням наборів EMAP-II ELISA - test KIT фірми BIOSOURSE EUROPESA на аналізаторі "Stat Fax 303 Plus" (USA); активність амілази - кінетичним методом за допомогою наборів « $\alpha$-АМІЛАЗА-кін. СпЛ» (Україна). Отримані дані статистично опрацьовані з використанням стандартного пакета програми Statistica 8,0 for Windows та пакета статистичних функцій програми Microsoft Exell. Вірогідність відмінностей між залежними та незалежними варіантами оцінювали за допомогою t-критерію Ст'юдента, відмінність вважали достовірною при р <0,05. Також обчислювали відношення шансів (odds ratio - OR), 95\% довірчий інтервал (95\% ДI), чутливість, специфічність, позитивну та негативну прогностичну цінність.

\section{Результати}

У 71,43\% хворих з ГП середнього ступеня тяжкості встановлено підвищення активності амілази сироватки крові до (249,5 $\pm 16,2)$ од./л, що в 1,9 разу перевищувало показник у здорових осіб - $(128,3 \pm 9,5)$ од./л (р < 0,05). У 53,3\% хворих з деструктивним панкреатитом активність амілази сироватки крові підвищувалась до (329,8 \pm 24,2) од/л, перевищуючи показник у здорових осіб у 2,9 разу (р $<0,05)$. У всіх пацієнтів, яким під час госпіталізації визначали активність фосфоліпази А2 і виявили ії підвищення до $(698,18 \pm 9,70)$ нг/мл, у подальшому було підтверджено деструктивний панкреатит, ускладнений перитонітом. У хворих з ГП середнього ступеня тяжкості, яким проводили консервативну терапію, активність фосфоліпази А2 становила $(392,77 \pm 15,59)$ нг/мл та у 3,2 разу перевищувала показник у здорових осіб - $(123,0 \pm 10,12)$ нг/мл $(\mathrm{p}<0,05)$.

Визначення рівня гістаміну в сироватці крові у хворих із ГП середнього ступеня тяжкості засвідчило його підвищення до $(2,28 \pm 0,12)$ нг/мл порівняно з показником у здорових осіб - $(0,70 \pm 0,11)$ нг/мл $(\mathrm{p}<0,001)$. У пацієнтів 3 деструктивним панкреатитом рівень гістаміну в сироватці крові перевищував показник у пацієнтів з ГП середнього ступеня тяжкості в 1,77 разу та становив $(5,10 \pm 0,34)$ нг/мл.

Рівень ЕМАП-ІІ підвищувався до $(1,836 \pm 0,132)$ нг/мл - при гострому деструктивному панкреатиті і до (1,032 $\pm 0,057)$ нг/мл - при ГП середнього ступеня тяжкості до початку лікування. У здорових осіб він становив $(0,234 \pm$ $0,120)$ нг/мл. Визначення шансів розвитку панкреатогенного перитоніту та поліорганної недостатності у хворих з ГП різного ступеня тяжкості у залежності від активності амілази, фосфоліпази А2 та рівня гістаміну показало, що у разі активності амілази вище 329,8 од./л OR становить 21,71 (р < 0,006), активності фосфоліпази А2 698,18 нг/ мл і вище - 49,65 (p=0,0001), рівня гістаміну 5,1 нг/мл і вище $-8,95(\mathrm{p}=0,001)$. Для прогнозу порушення функції печінки, нирок за таких активності амілази і фосфоліпази А2 та рівня гістаміну OR становить відповідно 16,63 $(\mathrm{p}=0,003), 34,44(\mathrm{p}=0,0003)$ та 11,54 (p=0,015). Рівень ЕМАП-II мав низьку прогностичну значущість, що, вірогідно, пов'язано з його поступовим зростанням по мірі деструкції тканини ПЗ.

\section{Обговорення}

Підвищення активності амілази в сироватці крові в 1,9 та 2,9 разу до початку вибору варіанта терапії відмічено відповідно лише у 71,43\% хворих з ГП середнього ступеня тяжкості та у 53,3\% хворих $з$ деструктивним панкреатитом. Якраз зростання у три і більше разів активності амілази і ліпази окремі дослідники розглядають як переконливі критерії ГП [3]. У той же час нормальні показники окремих панкреатичних ферментів у сироватці крові не спростовують діагнозу ГП [13]. На думку цих же авторів, визначення активності амілази та ліпази важливе для діагностики панкреатиту, але для визначення тяжкості захворювання його прогностична значущість низька.

Підвищення у хворих на передопераційному етапі активності фосфоліпази А2 у 5,7 разу дає підстави з високою вірогідністю прогнозувати деструктивний панкреатит. Отримані дані узгоджуються з результатами експериментальних досліджень щодо введення фосфоліпази А2 в тканину ПЗ, внаслідок чого формуються ознаки геморагічного панкреонекрозу, відбувається гнійне розплавлення окремих ацинусів, масивні крововиливи в міжчасточкову та внутрішньочасточкову інтерстиціальну тканину і розвивається жировий панкреонекроз [14]. Окрім того, фосфоліпаза підсилює активацію трипсиногену. Поряд з ферментами - фосфоліпазою, ліпазою, трипсином - в активації деструкції мембран ацинарних клітин ПЗ при ГП активну участь беруть біологічно активні речовини гістамін, ацетилхолін, адреналін. На думку Т. Francis i співавторів, регуляція рівня гістаміну може бути новим напрямком щодо стратегії лікування захворювань ПЗ [12]. Встановлене нами підвищення рівня гістаміну у 3,3 разу - при ГП середнього ступеня тяжкості та у 7,3 разу - при деструктивному панкреатиті на початку захворювання $є$ прогностичним маркером тяжкості перебігу захворювання, що підтверджено визначенням відношення шансів.

Підвищений вміст прозапальних цитокінів у тканині ПЗ, вірогідно, потенціює некроз і апоптоз панкреоцитів, а тривала цитокінова агресія супроводжується зростанням генералізованої судинної проникності, міграцією лейкоцитів, максимальним пошкодженням панкреоцитів, про що свідчить встановлене нами підвищення рівня ЕМАПII у 7,8 разу - при тяжкому ГП та у 4,4 разу - при ГП середнього ступеня тяжкості.

\section{Висновки}

1. На початковій стадії розвитку ГП у всіх хворих зростає активність фосфоліпази А2. Підвищення активності амілази вище 329,8 од./мл і фосфоліпази А2 вище 698,18 нг/мл дає підстави прогнозувати з великою вірогідністю (OR відповідно 21,71 і 49,65) розвиток тяжких ускладнень - панкреатогенного перитоніту, порушень функції печінки і нирок. 
2. Прогностично несприятливим щодо тяжкого перебігу ГП є підвищення рівня гістаміну в сироватці крові вище 5,1 нг/мл.

\section{References}

1. Benks PA, Bollen TL, Dervenis C, Gooszen HG, Jonson CD, Sarr MG, et al. Acute pancreatitis Classification Working Group. Classification of acute pancreatitis 2012: revision of the Atlanta classification and definicions by international consensus. Gut. 2013; 62 (1); 102-13. PMID: 23100216. DOI: 10.1136/gutjnl-2012-302779.

2. Improved algorithms for diagnosis and treatment of acute pancreatitis Methodical recommendations. Kyiv; 2012; 80 s. [In Ukrainian].

3. Rosolewski M, Lipinski M, Dobosz M, Durlik M, Gluszek S, Kusnierz $\mathrm{K}$, et al. Management of acute pancreatitis (AP) - Polich Pancreatic club recommendations. Prz. Gastroenterol. 2016; V 11(2); 65-72. PMID: 27350832. Doi: [10.5114/pg.2016.60251].

4. Stimac D, Mikolasevic I, Krznaric-Zrnic I, Radic M, Milic S. Epidemiology of Acute Pancreatitis in the North Adriatic Region of Croatia during the Last Ten Years. Gastroenterol. Res. Pract. V 2013; 2013: 956149. 5 pages. PMID: 23476641. doi: [10.1155/2013/956149].

5. Krishna SG, Kamboj AK, Hart PA, Hinton A, PhD, Conwell DL. The Changing Epidemiology of Acute Pancreatitis Hospitalizations: A Decade of Trends and the Impact of Chronic Pancreatitis. Pancreas. 2017 Apr; 46(4): 482-488. PMID: 28196021. DOI: 10.1097/ MPA.0000000000000783

6. Lankisch PG, Apte M, Banks A. Acute Pancreatitis. Gastroenterology of S.-Petersburg. 2015; Jul 4; 386(9988):85-96. PMID: 25616312. Doi: 10.1016/S0140-6736 (14) 60649-8.
7. Wu BU, Conwell DL. Update in acute pancreatitis. Curr Gastroenterol Rep. 2010 Apr; 12(2): 83-90. PMID: 20424979. doi: 10.1007/s11894 010-0091-6

8. Godlevskij BM, Potalov SA, Sid' YeB, Serov KV, Kajukiv AV. Trypsinogen-2 - Marker of Acute Pancreatitis: Possibilities for Use at the Prehospital Stage. Emergency medicine; 2014; №7 (62); 147-8. [In Ukrainian].

9. Gu H, Werner J, Bergmann F, Whitcomb DC, Buchler MW, Fortunato F. Necro-inflammatory response of pancreatic acinar cells in the pathogenesis of acute alcoholic pancreatitis. Cell Death \& Disease. [Internet] 2013; -4. PMID: 24091659. Doi 10. 1038/c ddis2013.354.

10. Panek J. Kusnierz-Cabala B, Dolecki M, Pietron J. Serum proinflammatory cytokine levels and white blood cell differential count in patients with different degrees of acute alcoholic pancreatitis. Polski przeglad chirurgiczny. 2012; 84; 230-37. PMID: 22763297. Doi: 10.2478/ v10035-012-0038-8.

11. Nevalainen TJ. Phospholipase A2 in acute pancreatitis: review. Am. J. Surg. 2007. Vol.194 (4). 828-32. DOI: doi.org 10.1016/j. amjsurg.2007.04.004.

12. Francis T, Graf A, Hodges K, Kennedy L, Hargrove L, Price M, et al. Histamine regulation of pancreatitis and pancreatic cancer a review of recent fingins. Hepatobiliary surgery and nutricion. 2013; Aug.2 (4); 216-26. PMID: 24570946. Doi: 10.3978/j.issn.2304-3881.2013.08.06.

13. Shah AM, Eggi R, Kothari ST. Acute Pancreatitis with normal serum lipase a care series. JOP. 2010; Jul 5; 11 (4); 369-72. PMID: 20601812.

14. Nieminen A, Maksimow M,,Mentula P, Kyhälä L, Kylänpää L, Puolakkainen P, Kemppainen E, Repo H, et al. Circulating cytokines in predicting development of severe acute pancreatitis. Crit Care. 2014; 18(3): R104. PMID: 24886762. doi: 10.1186/cc13885 